
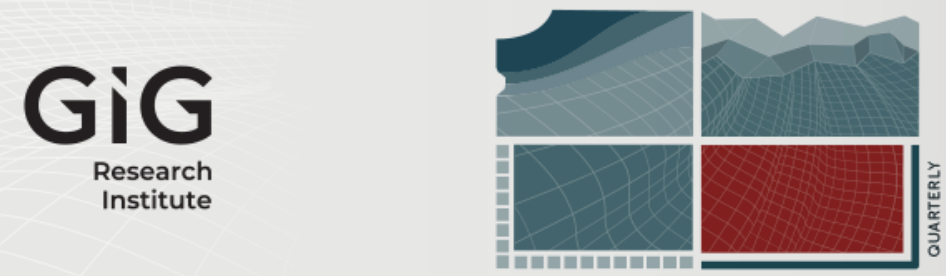

JOURNAL

OF

SUSTAINABLE

MINING

Volume 20 | Issue 2

Article 6

2021

\title{
The contribution of mining sector to sustainable development in Saudi Arabia
}

Author(s) ORCID Identifier:

Mourad Zmami (iD 0000-0002-8838-6512

Ousama Ben-Salha (iD) 0000-0002-0253-313X

Sultan O. Almarshad (D) 0000-0003-0178-5340

Houyem Chekki (D) 0000-0002-2493-4049

Follow this and additional works at: https://jsm.gig.eu/journal-of-sustainable-mining

Part of the Development Studies Commons, Econometrics Commons, Economic Policy Commons, Energy Policy Commons, Environmental Studies Commons, Mining Engineering Commons, and the Sustainability Commons

\section{Recommended Citation}

Zmami, Mourad; Ben-Salha, Ousama; Almarshad, Sultan O.; and Chekki, Houyem (2021) "The contribution of mining sector to sustainable development in Saudi Arabia," Journal of Sustainable Mining: Vol. 20 : Iss. 2 , Article 6.

Available at: https://doi.org/10.46873/2300-3960.1056

This Research Article is brought to you for free and open access by Journal of Sustainable Mining. It has been accepted for inclusion in Journal of Sustainable Mining by an authorized editor of Journal of Sustainable Mining. 


\title{
The contribution of mining sector to sustainable development in Saudi Arabia
}

\author{
Abstract \\ The mining sector development is among the priorities of the Saudi Vision 2030. There is currently a lot of \\ interest in the role of the mining sector in Saudi Arabia. This research contributes to this debate by \\ empirically assessing the effects of mining on sustainable development in Saudi Arabia during the period \\ 1980-2018. Unlike many previous studies, the three sustainable development dimensions, namely \\ economic, social, and environmental, are jointly considered. The cointegration analysis, based on the \\ ARDL, Gregory-Hansen, and combined cointegration tests, confirms the existence of long-run \\ relationships between mining and all sustainable development dimensions. Furthermore, the findings lend \\ substantial evidence on the importance of the mining sector in enhancing economic and social \\ sustainability in the short- and long-run. There is, however, no evidence of the existence of adverse \\ environmental effects of mining. The long-run effects of mining are robust to a battery of robustness and \\ stability tests. Suitable policy recommendations are subsequently reported.

\section{Keywords} \\ Mining, sustainable development, Saudi Arabia, cointegration \\ Creative Commons License \\ (c) (i) \\ This work is licensed under a Creative Commons Attribution 4.0 License.
}




\title{
The contribution of mining sector to sustainable development in Saudi Arabia
}

\author{
Mourad Zmami ${ }^{a}$,*, Ousama Ben-Salha ${ }^{a}$, Sultan O. Almarshad ${ }^{a}$, Houyem Chekki ${ }^{b}$ \\ ${ }^{\text {a N}}$ Northern Border University, Arar, Saudi Arabia \\ ${ }^{\mathrm{b}}$ University of Manouba, Manouba, Tunisia
}

\begin{abstract}
The mining sector development is among the priorities of the Saudi Vision 2030. There is currently a lot of interest in the role of the mining sector in Saudi Arabia. This research contributes to this debate by empirically assessing the effects of mining on sustainable development in Saudi Arabia during the period 1980-2018. Unlike many previous studies, the three sustainable development dimensions, namely economic, social, and environmental, are jointly considered. The cointegration analysis, based on the ARDL, Gregory-Hansen, and combined cointegration tests, confirms the existence of long-run relationships between mining and all sustainable development dimensions. Furthermore, the findings lend substantial evidence on the importance of the mining sector in enhancing economic and social sustainability in the shortand long-run. There is, however, no evidence of the existence of adverse environmental effects of mining. The long-run effects of mining are robust to a battery of robustness and stability tests. Suitable policy recommendations are subsequently reported.
\end{abstract}

Keywords: mining, sustainable development, Saudi Arabia, cointegration

\section{Introduction}

$\mathrm{T}$ he mining sector is often considered as an important contributing factor to sustainable development goals in mineral-rich countries. On the economic level, the sector accounts for a substantial share of production and exports in those countries and represents a significant source of financial revenues for governments. The development of the mining sector seems to be mandatory for the accumulation of public and human capital, as mineral revenues can be used to finance human and physical capital expenditures [1]. On the social level, many benefits can be gained from mining exploration and exploitation, and perhaps the most noticeable is job creation $[2,3]$. Other social effects, particularly on per capita consumption expenditure, poverty, migration, and corporate social responsibility activities, have also been discussed in the literature $[4,5]$.
The above discussion suggests that mineral resources represent an opportunity for resourceabundant countries. Indeed, some developed countries, including Australia and Norway, have mobilized mineral resource rents to support economic development and improve well-being $[6,7]$. Similarly, mining has been a significant pillar of growth in some developing countries. Mbilima [8] reports that the share of mineral exports in low and middle-income mineral-abundant countries range between $30 \%$ and $60 \%$ of total exports, while foreign direct investments in the mining sector range between $60 \%$ and $90 \%$. In Zambia, the mining sector contributed around $77.65 \%$ of exports and $32 \%$ of government revenues in 2014 [8]. In the Democratic Republic of Congo, the mining sector accounted for $94.9 \%$ of total exports, $55.16 \%$ of total government revenues, and $17.4 \%$ of the gross domestic product in 2017 [9]. Nevertheless, it is worth mentioning that mining projects not only have positive effects on the economy and society. The experience of many countries with large extractive industries reveals the

Received 11 February 2021; revised 6 April 2021; accepted 7 May 2021

Available online 18 June 2021

* Corresponding author.

E-mail address: mourad.zmami@nbu.edu.sa (M. Zmami). 
presence of detrimental impacts of mineral exploration and exploitation on the environment [10-12]. Therefore, mineral-rich countries are always seeking to get the most out of the mining sector expansion in terms of socio-economic development while minimizing its adverse environmental effects.

According to the above discussion, analysing the performance of the mining sector involves assessing its effects on the three pillars of sustainable development, namely the economy, society, and environment. Within this background, this research addresses the contribution of the mining sector to sustainable development in Saudi Arabia. Saudi Arabia presents an interesting case study to investigate the role of the mining sector in reaching sustainable development goals. Indeed, to mitigate the economic and social risks that may arise following sharp drops in oil prices, substantial efforts are being made to diversify the Saudi economy, mainly by expanding sectors other than the oil-related ones. The mining sector is one of the potential emerging sectors that could play an essential role in the economy. Regarding this issue, the Saudi Vision 2030 aims to transform the mining sector into a strategic sector that contributes to economic diversification, increased added value, and job creation. More specifically, the objective of the National Mining Strategy 2030 is to increase the GDP contribution of the mining sector from 21 billion USD in 2015 to about 70 billion USD and create 250,000 additional jobs by 2030 [13]. The expansion of the mining sector raises a key question about its contribution to reaching sustainable development goals in Saudi Arabia. More specifically, this research investigates empirically the effects of the mining sector on the three pillars of sustainable development (economy, society, and environment) in Saudi Arabia between 1980 and 2018. The empirical investigation is based on the Autoregressive Distributed Lag (ARDL) bounds testing approach developed by Pesaran [14]. To check the robustness of findings, we also employ the Gregory-Hansen cointegration test that accounts for potential structural breaks and the combined cointegration test developed by Bayer [15]. Moreover, the long-run effects of mining activities on the different sustainable development dimensions are estimated using various techniques, such as the fully modified ordinary least squares (fully modified OLS) and the dynamic ordinary least squares (dynamic OLS).

Compared to the existing literature, the current research presents some novelties. First, to the best of our knowledge, this study is one of the very few to carry out a macro-econometric analysis when exploring the outcomes of the mining sector. Indeed, most works concentrated on analysing the consequences of mining at regional levels $[5,16]$. Second, the current study is the first to simultaneously assess the effects of the mining sector on the three pillars of sustainable development, namely economic, social, and environmental. Indeed, some prior works focused on the impact of the mining sector on the economy $[17,18]$, society $[5,19]$, and the environment [12]. Nevertheless, none of them considered all three dimensions of sustainability. Finally, the conducted empirical analysis allows estimating the short- and long-run effects of the mining sector on sustainable development.

The remainder of this paper is organized as follows. Section 2 presents the literature on the impact of mining on economic, social, and environmental sustainability, while Section 3 illustrates the evolution of the mining sector in Saudi Arabia. The econometric methodology and data are described in Section 4 . Sections 5 and 6 are devoted to discussing the main empirical results and performing various robustness and sensitivity checks, respectively. Finally, Section 7 concludes the paper and suggests some policy recommendations.

\section{Sustainable mining: theory and empirics}

\subsection{Mining and economic sustainability}

Mineral resources may positively affect economic growth through many channels. First, mineral resources are crucial for many industries by providing them with mandatory raw materials. Second, mining revenues feed the state budget and allow developing countries to generate new economic opportunities. Third, the mining sector may stimulate the development of other associated activities, including office supplies and equipment, spare parts, machinery, maintenance services [20]. However, several arguments support the existence of detrimental effects of mineral resources on economic growth. The first argument, developed by Prebisch [21] and Singer [22], is based on the deterioration of the terms of trade in mineral resourceproducing countries. The authors argue that when a country specializes in the production and export of mining products, there will be a fall in the prices of exported raw materials of mining products and a rise in the prices of imported manufactured goods [23]. This situation leads to a deterioration of the terms of trade in developing countries, which may damage long-run growth. The famous Dutch disease is another argument against the positive economic effects of mining. According to this 
hypothesis, more natural resource-based activities, including mining activities, may be usually associated with a shift in the structure of the economy by concentrating more economic activity in the mining sector. Mineral resource abundance discourages diversifying the economy and makes it vulnerable to shocks. The depletion of mineral resources is another argument against the presence of positive long-term connections between mining and economic growth. According to Cowell [24], mineral resources are limited and non-renewable, limiting the opportunities of future generations to access these resources.

On the empirical ground, Stern [25] examines the impact of mining on economic sustainability in a sample of 19 mineral-abundant countries between 1963 and 1988 and suggests that the positive longrun effects of mining are not supported for all countries. Using a Bayesian Averaging of Classical Estimates approach, Sala-i-Martin [17] conclude that the share of mining in GDP is among the drivers of long-run growth in a sample of 88 countries. Douglas [26] examine the effects of coal mining on economic growth in 409 U.S. counties between 1970 and 2010. The GMM-based panel data analysis indicates that a one standard deviation increase in mining resource dependence induces a decline of the short- and long-term growth rate of per capita income by $0.2 \%$ and $0.5-1 \%$, respectively. Recently, Sangare [18] analyses the effects of mining rents in Niger. The research investigates how mineral resource rent may be used to finance road infrastructure, which may positively impact production and employment in other sectors of the economy.

\subsection{Mining and social sustainability}

Mining projects are likely to significantly affect social indicators, such as poverty, employment, and corporate social responsibility. The subject has been investigated empirically in the recent literature. For example, Ticci [4] examine the impact of mining on the labor market, migration, and poverty in Peru and come to some important conclusions. First, mining activities attracted migration flows to areas where they are concentrated. Moreover, the findings confirm adverse effects on agricultural employment and positive effects on access to primary and secondary education. Loayza [5] also investigates the socioeconomic impacts of mining in Peruvian communities. According to the findings, mining districts have higher per capita consumption than other districts, while poverty rates are lower. Gueye [19] reveal that near-community mining sites positively affect education in Canada. Young people are more motivated to complete their studies as there are good prospects of well-paid careers in the mining industry. Recently, Syahrir [3] focuses on the social outcomes of mining operations on the Indonesian island of Singkep. Empirical results confirm that mining operations positively impact employment, educational and health facilities, and infrastructure. However, these effects are not permanent as they disappear with the closing of the mining site. Focusing on the United Republic of Tanzania, Kitula [2] reveals that about $42 \%$ of questionnaire respondents claim they have earned jobs in the mining sector, while $20.3 \%$ benefited from improved road networks and water and school constructions. Kotsadam [27] analyse the impact of mining on employment in a sample of 874 large mining sites in 29 African countries. The study highlights that mining openings create new off-farm employment opportunities. Moreover, men are moving into skilled manual jobs, while women are redeploying to services. Finally, the research shows that men switch to farming after the mine closes, while women leave the labor force.

\subsection{Mining and environmental sustainability}

The environmental outcomes of mining might affect water, biodiversity, air, soil quality, spatial degradation, and transformation of mining areas [12,28-30]. Mining cities are the primary victims of environmental degradation due to solid, liquid, and gas pollutants caused by mining activities. Indeed, the implementation of mining infrastructures, such as roads, drilling, and tailings ponds, requires land clearing, excavation, and backfilling. These activities lead to land-use transformation and soil degradation. Moreover, the mining sector is responsible for increasing greenhouse gas emissions, such as carbon dioxide, in two ways. On the one hand, mining activities are often associated with deforestation and affect the capacity to absorb carbon dioxide emissions. On the other hand, explosives and fossil fuel energy sources required for mining activities lead to increased greenhouse gas emissions. The detrimental environmental effects of mining activities have been discussed in depth by Dudka [31]. According to the authors, the extraction of lead, copper, and zinc is responsible for the highest environmental degradation from mining operations. Indeed, the copper industry generates a lot of mine waste, while various greenhouse gases, such as 
carbon dioxide and Sulfur dioxide, are emitted during the smelting and processing of metals. ShaSha [32] shed light on the adverse impact of magnesite mining, including concentrating ores and grinding, on soil quality. From their part, Wright [33] and Mhlongo [34] focus on the detrimental effects of mining activities on water quality. Price [35] claim that water contamination caused by coal mines may be reported in both active and closed mines.

Empirically speaking, mining activities are still commonly proven to be a threat to the environment. Sahsah [10] confirms the responsibility of the extensive mining infrastructure for the degradation of soil, agricultural land, and rural settlements in Morocco. The adverse environmental effects of mining in Morocco have also been identified by El Hachimi [16], who examine the case of the Zeida mining center in Haute Moulouya. The study concludes that the abandoned mining site affects not only the air quality but also surface water and sediments that have been polluted by toxic trace metal elements. In another research, Kitula [2] indicates that increasing mining activities lead to water contamination and buildings collapse in the United Republic of Tanzania. The detrimental effects of mining activities on the environment have also been highlighted by Brahmi [11] for the case of Tunisia. This study reveals that mining operations in Gafsa district are responsible for environmental damages related to dust, wastewater, and atmospheric emissions. Mabey [12] investigate the environmental impact of mining in Sierra Leone using a questionnaire-based dataset collected by surveying communities in various mining areas. The empirical analysis shows that, despite its contribution to the development of Sierra Leone, the mining sector has resulted in adverse environmental consequences, including deforestation, air pollution, and lack of clean water. Sha-Sha [32] focus on soil quality, assessed based on various indicators such as soil $\mathrm{PH}$, the ratio of magnesium to calcium, the bulk density in a sample of magnesite mining sites in Northeast China. The main conclusion of the study is that the soil quality in mining areas was poorer than in other areas. Such findings may be criticized since they do not mean the responsibility of mining operations in soil degradation. Sairinen [36] study the case of Talvivaara Mining Company in Finland and claim that the levels of sodium, sulfate, and manganese in wastewater were significantly higher than standard levels. Finally, Li [37] investigate the effects of coal mining on the existence of toxic metals in 103 soil samples in the Chinese province of Shandong. The authors reveal the responsibility of coal mining operations in increasing the concentration of the farmland tillage soil in toxic metals.

\section{The mining sector in Saudi Arabia}

Historically, the mining sector has not played a significant part in the Saudi economy, primarily due to the abundance of oil and natural gas. Small mining projects started in the seventies and eighties. However, with the creation of the Saudi Arabian Mining Company (Ma'aden) in 1997, the mining industry began experiencing radical transformations. The Saudi government entirely owned $M a^{\prime}$ aden until 2008 , and then, $50 \%$ of its shares were made available to investors on the Saudi Stock Exchange. As for 2018, the Public Investment Fund of Saudi Arabia remains the biggest shareholder with $65.44 \%$ of shares. According to S\&P Global Market Intelligence [38], Ma'aden is among the top 25 mining companies in the world, with a market capitalization of US $\$ 16.31$ billion at the end of $2017 .^{1}$ The principal metals and minerals produced by the company include gold, copper, aluminum, and phosphates. In 2015, mineral exports of $M a^{\prime} a d e n$ reached 2.6 million metric tons of diammonium phosphate, 611,000 metric tons of aluminum, 461,000 tons of ammonia, and $5100 \mathrm{~kg}$ of gold [39].

Adopted in recent years, the Saudi Vision 2030 targeted transforming the mining sector into a strategic sector that would contribute to achieving economic diversification, increasing added value, and providing job opportunities. In 2018, the National Mining Strategy for the development of the mining sector had been adopted. The plan aims to overcome obstacles faced by local and foreign investors. It also provides a set of factors for developing the mining sector in terms of production, exports, and foreign participation. Measures to develop the mining sector include, but are not limited to, the reinforcement of the legal system, the improvement of infrastructure and logistic facilities (transportation networks, industrial zones, seaports), the launch of a specific mineral exploration and exploration fund, the development of a geological database on belts and mineral deposits for investors, and the establishment of gold processing centres in the northern and central regions

\footnotetext{
1 www.spglobal.com/marketintelligence/en/news-insights/research/18-top-25-mining-companies-by-market-cap.
} 
of Saudi Arabia. These measures led to a steady development of the mining sector in Saudi Arabia during the last years. Data suggest the presence of 330 sites with a total exploration and extraction area of about 118,000 square kilometres, while the annual mineral production was about 450 million tons. In 2019, gold and silver productions were respectively 12353 and $5588 \mathrm{~kg}$, while the production of copper and zinc reached 63357 and 18900 tons. Saudi Arabia was the world's third-ranked producer of directreduced iron in 2015. Moreover, it was among the top producers of ammonia, cement, and sulfur in the world [39].

\section{Materials and methods}

\subsection{Econometric modelling and data}

This section empirically examines the effects of mining on sustainable development in Saudi Arabia during the period 1980-2018. Sustainable development $(S D)$ is modeled as a function of the mining activity and a set of control variables. Therefore, sustainable development during year $t$ can be modeled as follows:

$S D_{t}=\lambda_{0}+\lambda_{1}$ mining $+\phi^{\prime} Z_{t}+\epsilon_{t}$

where $S D$ represents the dependent variable (sustainable development). More specifically, we consider the effects of mining on three dimensions of sustainable development, namely economic sustainability, social sustainability, and environmental sustainability; mining is a proxy for mineral resources and represents our interest variable in this study. Finally, $Z$ is a matrix of control variables affecting each dimension of sustainable development (economic, social, and environmental). Theoretically speaking, these control variables represent the determinants of each dimension of sustainable development and are selected based on the previous theoretical and empirical literature. Consequently, the following three models are estimated:

\subsubsection{Model 1: economic sustainability}

To examine the effects of mineral resources on economic sustainability, the following model is estimated:

$$
\begin{aligned}
\text { Ec }_{t}= & \alpha_{0}+\alpha_{1} \text { mining }+\alpha_{2} \text { invest }_{t}+\alpha_{3} \text { gexpend }_{t} \\
& +\alpha_{4} \text { topen }_{t}+\mu_{t}
\end{aligned}
$$

where $E c S$ represents economic sustainability as measured by GDP per capita, while mining is measured by mineral resource rents. Regarding control variables affecting economic sustainability, Eq. (2) also includes investment (invest), government expenditure (gexpend), and trade openness (topen). The first control variable that may affect GDP per capita is investment. The contribution of investment to economic growth has been widely discussed, and a consensus on the importance of investment for economic growth has been reached [40,41]. The impact of investment on GDP per capita is assumed to be positive as it refers to the acquisition of capital goods mandatory for production. Based on the previous literature, the impact of the government of expenditure on economic growth is ambiguous [42]. It may be positive as a rise of public expenditure stimulates infrastructure and economic growth or negative because the more the government consumption is high, the more it needs resources to finance its deficit. Finally, Trade openness, measured by the sum of exports and imports divided by GDP, may stimulate economic sustainability by promoting specialization and facilitating imports of technology and capital goods. It has been shown that open economies grow faster than closed economies $[43,44]$.

\subsubsection{Model 2: social sustainability}

To examine the effects of mineral resources on social sustainability, the following model is estimated:

$$
\begin{aligned}
S_{o S} S_{t}= & \beta_{0}+\beta_{1} \text { mining }+\beta_{2} G D P_{t}+\beta_{3} k_{\text {stock }} \\
& +\beta_{4} \text { crapital }_{t}+\vartheta_{t}
\end{aligned}
$$

Where SoS represents social sustainability as measured by total employment, while mining is measured by mineral resource rents. Three variables are retained as control variables, namely gross domestic product (GDP), physical capital stock (kstock), and human capital (hcapital). The positive impact of gross domestic product on employment has been identified by abundant literature [45-47]. Indeed, periods of economic expansion are often associated with more employment opportunities and job creation and vice versa [48]. The second control variable is capital stock. The aim of introducing this variable is to examine the validity of the capital-labor complementarity hypothesis. Indeed, the capital stock may be complementary to labor if a rise of capital stock is associated with more job creation or substitutable to labor if a rise of capital stock destructs existing jobs [49,50]. Finally, we introduce human capital in Eq. (3). Theoretically, high human capital is a synonym of high skills and qualifications, which are often required to join the labor market and obtain a job [51]. 


\subsubsection{Model 3. environmental sustainability}

To examine the effects of mineral resources on environmental sustainability, the following model is estimated:

$$
E n S_{t}=\delta_{0}+\delta_{1} \text { mining }+\delta_{2} \mathrm{GDPC}_{t}+\delta_{3} \text { energy } y_{t}+\delta_{4} \text { topen }_{t}+\pi_{t}
$$

where EnS represents environmental sustainability as measured by carbon dioxide emissions per capita. $^{2}$ As for other dimensions, mining is measured by mineral resource rents. For the other variables explaining environmental sustainability, we use GDP per capita $(G D P C)$, total energy consumption per capita (energy), and trade openness (topen). ${ }^{3}$ First, as measured by GDP per capita, economic activity is among the most important factors influencing environmental degradation. According to Grossman [55], higher GDP requires more input materials, which is often associated with more polluting emissions. Energy consumption is also an important determinant of environmental degradation. The nature of the relationship between energy consumption and environmental degradation is ambiguous. Fossil fuel non-renewable energy consumption (oil, natural gas, coal) are considered as the primary source of environmental pollution and climate change [56,57], while the use of clean energy sources (nuclear, solar, wind, hydropower, etc.) allows reducing polluting emissions and improving the environment [53-58]. Finally, trade openness may significantly impact environmental degradation in open economies. The impact of trade openness on the environment received an ongoing debate as trade openness may deteriorate the environment by fostering the import of raw materials and technologies from abroad and consequently the development of polluting industries, especially in countries where environmental regulations are lacking [59]. Moreover, exports of goods could accelerate the depletion of natural resources, leading to increased $\mathrm{CO}_{2}$ emissions [60]. On the contrary, trade openness may decrease $\mathrm{CO}_{2}$ emissions by facilitating the import of clean technologies, allowing electricity production with less $\mathrm{CO}_{2}$ emissions [61].

\subsection{Econometric strategy}

The econometric strategy implemented in this paper involves a three-stage procedure:

- We start by testing the presence of unit root among variables. To this end, we apply the Dickey-Fuller Generalized Least Squares (DFGLS) unit root test proposed by Elliott [62]. However, given the relatively long period and the potential existence of structural breaks, we also used the unit root test with structural breaks developed by Saikkonen [63] and Lanne [64].

- Next, we check the existence of long-run relationships between mining and sustainable development. We start by using the ARDL bounds testing approach developed by Pesaran [14]. The general form of the ARDL $(p, q)$ may be written as follows:

$$
\Delta y_{t}=\alpha+\sum_{j=1}^{p} \rho_{j} \Delta y_{t-j}+\sum_{j=0}^{q} \gamma_{j} \Delta x_{t-j}+\delta_{1} y_{t-1}+\delta_{2} x_{t-1}+\epsilon_{t}
$$

where $y$ is the dependent variable (sustainable development), $x$ is the set of explanatory variables, including mining, and $\Delta$ is the first difference operator. The estimation of Eq. (5) allows examining the presence of cointegration between $x$ and $y$. The Schwarz Bayesian Criterion was used to detect the optimal lag order of the ARDL model, while the critical values proposed by Kripfganz [65] are used to assess the presence of cointegration. ${ }^{4}$ As a robustness check, we also implement the cointegration test with structural breaks proposed by Gregory [66,67]. Four models are considered in the Gregory-Hansen cointegration test:

-model 1: level shift (C)

$y_{t}=\mu_{1}+\mu_{2} \varphi_{t \tau}+\alpha^{T} x_{t}+e_{t} \quad t=1, \ldots, n$

-model 2: level shift with trend (C/T)

$y_{t}=\mu_{1}+\mu_{2} \varphi_{t \tau}+\beta t+\alpha^{T} x_{t}+e_{t} \quad t=1, \ldots, n$

\footnotetext{
${ }^{2}$ We are aware of the importance of other environmental aspects, such as land-use transformation, soil degradation, deforestation, water pollution and biodiversity. However, these variables are not available at the country-level. Previous studies that analysed the effects of mining on those aspects are based on questionnaire datasets. For the case of Saudi Arabia and many other countries, the variable that is available during relatively long periods consists of $\mathrm{CO}_{2}$ emissions. $\mathrm{CO}_{2}$ emissions are widely used in country-level studies as a proxy of environmental degradation [52-54].

${ }^{3}$ Table A1 in Appendix presents definitions and sources of variables. All variables included in the empirical analysis are expressed in the natural logarithm.

Critical values are obtained by estimating response surface models based on about 95 billion simulated F-statistics and 57 billion $\mathrm{t}$-statistics [65].
} 
Table 1. Results of unit root tests.

\begin{tabular}{|c|c|c|c|c|c|c|c|}
\hline \multirow[t]{3}{*}{ Variables } & & \multicolumn{2}{|c|}{ DF-GLS unit root test } & \multicolumn{4}{|c|}{ Saikkonen-Lütkepohl structural break unit root test } \\
\hline & & \multirow{2}{*}{$\frac{\text { level }}{\text { t-statistic }}$} & \multirow{2}{*}{$\frac{1 \text { st diff. }}{\text { t-statistic }}$} & \multicolumn{2}{|l|}{ level } & \multicolumn{2}{|l|}{ 1st diff. } \\
\hline & & & & t-statistic & $\mathrm{T}_{\mathrm{B}}$ & t-statistic & $\mathrm{T}_{\mathrm{B}}$ \\
\hline EcS & & -1.987 & $-4.858^{* * *}$ & -1.197 & 1985 & $-4.040^{* * *}$ & 1986 \\
\hline EnS & & -2.734 & $-7.126^{* * *}$ & -1.690 & 1991 & $-7.465^{* * *}$ & 1994 \\
\hline SoS & & -1.646 & $-4.529^{* * *}$ & -1.765 & 1988 & $-4.768^{* * *}$ & 1987 \\
\hline mining & & -2.221 & $-3.278^{* *}$ & -2.370 & 2012 & $-4.323^{* * *}$ & 2012 \\
\hline topen & & -1.718 & $-4.656^{* * *}$ & -1.620 & 2000 & $-2.776^{*}$ & 2001 \\
\hline energy & & -1.950 & $-4.866^{* * *}$ & -1.589 & 1991 & $-3.470^{* *}$ & 1990 \\
\hline invest & & -2.466 & $-4.997 * * *$ & -2.256 & 1985 & $-4.351^{* * *}$ & 1985 \\
\hline gexpend & & -2.285 & $-5.245^{* * *}$ & -0.916 & 2009 & $-4.002^{* * *}$ & 2009 \\
\hline GDP & & -2.108 & $-5.184^{* * *}$ & -1.075 & 1986 & $-3.623^{* * *}$ & 1986 \\
\hline hcapital & & -1.573 & $-3.236^{* *}$ & -0.347 & 2001 & $-4.115^{* * *}$ & 2009 \\
\hline kstock & & $-3.978^{* * *}$ & -2.052 & -2.588 & 2009 & $-3.278^{* *}$ & 2009 \\
\hline \multirow{3}{*}{ Critical values } & $1 \%$ & -3.77 & & -3.55 & & & \\
\hline & $5 \%$ & -3.19 & & -3.03 & & & \\
\hline & $10 \%$ & -2.89 & & -2.76 & & & \\
\hline
\end{tabular}

Note: ${ }^{* * *}, * *$, and $*$ denote the rejection of the unit root null hypothesis at the $1 \%, 5 \%$, and $10 \%$ levels, respectively. TB refers to the date of the time break.

-model 3: regime shift $(\mathrm{C} / \mathrm{S})$

$y_{t}=\mu_{1}+\mu_{2} \varphi_{t \tau}+\alpha_{1}^{T} x_{t}+\alpha_{2}^{T} x_{t} \varphi_{t \tau}+e_{t} \quad t=1, \ldots, n$

-model 4: regime and trend shift (C/S/T)

$y_{t}=\mu_{1}+\mu_{2} \varphi_{t \tau}+\beta_{1} t+\beta_{2} t \varphi_{t \tau}+\alpha_{1}^{T} x_{t}+\alpha_{2}^{T} x_{t} \varphi_{t \tau}+e_{t}$

$t=1, \ldots, n$

According to Gregory [35], the dummy variable that indicates the structural change is defined as follows:

$\varphi_{t \tau}=\left\{\begin{array}{llll}0 & \text { if } & \leq & {[n \tau]} \\ 1 & \text { if } & > & {[n \tau]}\end{array}\right.$

The null hypothesis of the Gregory-Hansen test is that residuals exhibit a unit root, i.e., there is no cointegration, while the alternative is the presence of cointegration with a single unknown break. The breakpoint is the one giving the least support for the null hypothesis of a unit root in the residuals. ${ }^{5}$ Finally, we employ the combined cointegration test proposed by Bayer [15]. The advantage of this test is that it combines four different cointegration tests, namely those developed by Engle [68], Johansen [69], Boswijk [70], and Banerjee [71], and consequently allows testing the presence of cointegration using different procedures and avoiding the conduct of individual tests. The two variants of the combined cointegration test are computed as follows:

$$
\begin{aligned}
& E G-J O H=-2\left[\ln \left(P_{E G}\right)+\ln \left(P_{J O H}\right)\right] \\
& E G-J O H-B O-B D M= \\
& \quad-2\left[\ln \left(P_{E G}\right)+\ln \left(P_{J O H}\right)+\ln \left(P_{B O}\right)+\ln \left(P_{B D M}\right)\right]
\end{aligned}
$$

where $E G, J O H, B O$ and $B D M$ represent the Engle [68], Johansen [69], Boswijk [70], and Banerjee [71] tests, while $P$ is the $p$-value of the different cointegration tests.

- We move to the estimation of long- and short-run effects of mining on sustainable development. The long-run coefficients are estimated using the following ARDL model:

$$
y_{t}=\alpha+\sum_{j=1}^{n} \gamma_{j} y_{t-j}+\sum_{j=0}^{m} \vartheta_{j} x_{t-j}+\mu_{t}
$$

For robustness checks, the fully-modified OLS suggested by Phillips [72] and the dynamic OLS suggested by Stock [73] are also conducted to estimate the long-run effects. The short-run effects are estimated using the error correction model:

$\Delta y_{t}=\alpha+\sum_{j=1}^{p} \rho_{j} \Delta y_{t-j}+\sum_{j=0}^{q} \gamma_{j} \Delta x_{t-j}+\theta E C T_{t-1}+\pi_{t}$

where ECT is the error correction term derived from the corresponding long-run equilibrium relationship.

\footnotetext{
${ }^{5}$ More details may be obtained from Gregory [66]
} 


\section{Results and discussion}

\subsection{Unit root testing}

As outlined earlier, the empirical investigation begins by checking the stationarity of variables introduced in the analysis. Findings of unit root tests for series in level and first difference are reported in Table 1.

The DF-GLS unit root test indicates that levels of all variables, except capital stock, have a unit root, i.e., they are not stationary in levels. When considering the first difference of variables, the same table suggests that most of them become stationary at a $1 \%$ level. As the DF-GLS test may present some deficiencies in the presence of structural breaks, we also report the statistics and break dates of the Saikkonen [63] and Lanne [64] unit root test. As shown, the null hypothesis of unit root cannot be rejected for all variables, including the capital stock. On the contrary, all variables are stationary in the first difference. Moreover, the test suggests that most macroeconomic variables, such as GDP and investment, have been subject to structural breaks in 1985-1986, due essentially to the fall of oil production in Saudi Arabia from 10 million barrels per day in 1980 to less than 2.5 million barrels per day in 1985-1986. All in all, the unit root tests strongly confirm that variables are integrated at first difference. Consequently, one may test the presence of long-run relationships between mineral resource rents and the different sustainable development dimensions.

\subsection{Testing for cointegration}

Having established that all variables are integrated of order 1 , we move to the cointegration analysis between mineral resource rents and the three sustainable development dimensions (economic, social, and environmental). The ARDL bounds testing approach results using the critical values proposed by Kripfganz [65] based on a response surface regression, as well as some diagnostic tests are reported in Table 2.

We begin with the economic dimension, for which the ARDL modeling checks the presence of longrun linkages between GDP per capita, mineral resource rents, investment, trade openness, and government expenditure. The F-statistic and t-statistic reveal that the null hypothesis of no cointegration is rejected at $1 \%$ level and $5 \%$ level, respectively. Consequently, the ARDL confirms the presence of a long-run relationship between mineral resource rents and economic sustainability. Turning to the social dimension of sustainable development, the F-statistic and t-statistic confirm the presence of a long-run relationship between employment and mineral resource rents. The rejection of the null hypothesis is confirmed at the $1 \%$ level based on the two aforementioned tests, representing a solid argument on the long-run social effects of mining in Saudi Arabia. Finally, testing the existence of a long-run association between environmental sustainability and mineral resource rents yields results different from what has been reached for economic and social sustainability. Indeed, the F-statistic ranges between the $10 \%$ lower and upper bounds, which means that no conclusion on the presence of cointegration may be drawn. On the contrary, the t-statistic confirms cointegration at the $10 \%$ level. Overall, one may conclude the existence of weak cointegration between environmental degradation, mineral resource rents, energy

Table 2. Results of the ARDL bounds test for cointegration.

\begin{tabular}{|c|c|c|c|c|c|}
\hline \multicolumn{6}{|c|}{ Panel A. Bounds testing for cointegration } \\
\hline Dimension & \multicolumn{2}{|l|}{ Model } & F-statistic & t-statistic & Decision \\
\hline Economic & \multicolumn{2}{|c|}{$E c S=f($ mining, invest, topen, gexpend $)$} & $8.522^{* * *}(0.001)$ & $-4.670^{* *}(0.016)$ & cointegration \\
\hline Social & \multicolumn{2}{|c|}{ SoS $=f($ mining $, G D P, k s t o c k$, hcapital $)$} & $15.915^{* * *}(0.000)$ & $-7.291^{* * *}(0.000)$ & cointegration \\
\hline Environmental & \multicolumn{2}{|c|}{$E n S=f($ mining, energy, topen, GDPC $)$} & $3.734(0.114)$ & $-3.820^{*}(0.079)$ & cointegration \\
\hline \multicolumn{6}{|c|}{ Panel B. Diagnostic tests } \\
\hline \multicolumn{2}{|l|}{ Model } & LM test & $\mathrm{ARCH}$ test & Normality test & RESET test \\
\hline \multicolumn{2}{|c|}{$\overline{E c S}=f($ mining, invest, topen, gexpend $)$} & 0.135 & 0.043 & 0.884 & 0.136 \\
\hline \multicolumn{2}{|c|}{ SoS $=f($ mining,$G D P$, kstock, hcapital $)$} & 0.989 & 0.389 & 0.000 & 0.906 \\
\hline \multicolumn{2}{|c|}{ EnS $=f($ mining, energy, topen,$G D P C)$} & 0.356 & 0.240 & 0.995 & 0.730 \\
\hline \multicolumn{6}{|c|}{ Panel C. Kripfganz and Schneider's (2020) response surface regression-based critical values } \\
\hline \multirow{2}{*}{ Critical values } & & & $10 \%$ & $5 \%$ & $1 \%$ \\
\hline & \multirow[t]{2}{*}{ F-statistic } & $\mathrm{I}(0)$ & 2.690 & 3.256 & 4.599 \\
\hline & & $\mathrm{I}(1)$ & 3.872 & 4.585 & 6.258 \\
\hline & \multirow[t]{2}{*}{ t-statistic } & $\mathrm{I}(0)$ & -2.572 & -2.919 & -3.628 \\
\hline & & $\mathrm{I}(1)$ & -3.679 & -4.083 & -4.898 \\
\hline
\end{tabular}

Notes: The Schwarz information criterion is used to select the optimal lag length for the ARDL model. The critical values are derived from Kripfganz [65]. *****, and * denote the rejection of the null hypothesis of no cointegration at 1,5 , and $10 \%$, respectively. For panel $\mathrm{B}, \mathrm{p}$-values are reported. 
consumption, trade openness, and gross domestic product. Panel B of Table 2 suggests that the three ARDL models generally pass multiple diagnostic tests, including the Breusch Godfrey Lagrange multiplier test for residual serial correlation, the autoregressive conditional heteroscedasticity test, the Jarque-Bera normality test, and Ramsey's test for functional misspecification.

To summarize, the ARDL approach confirms the presence of robust long-run relationships between mineral resource rents on the one hand and economic and social sustainability on the other hand. However, there is little evidence of the existence of long-run environmental effects of mining. In what follows, we will estimate the long-run and short-run effects of mineral resource rents on the economic, social, and environmental dimensions of sustainable development.

\subsection{Long- and short-run effects of mining}

Having confirmed the long-run linkages between mineral resource rents and the three sustainable development dimensions, long- and short-run effects are estimated. The ARDL approach is used to estimate the long-run effects, while the short-run effects are derived from the error correction model. Results are reported in Table 3.

Starting with economic sustainability, findings show that the long-run coefficient of mining is positive and statistically significant at $5 \%$. Such results strongly confirm the existence of long-run positive effects of mineral resource rents on economic sustainability. As previously highlighted,

Table 3. Long- and short-run effects of mining.

\begin{tabular}{llllll}
\hline \multirow{2}{*}{ Dimension } & \multicolumn{2}{l}{ Long-run effects } & & \multicolumn{2}{l}{ Short-run effects } \\
\cline { 2 - 3 } \cline { 5 - 6 } & Coef. & $p$-value & & Coef. & $p$-value \\
\cline { 1 - 2 } Economic sustainability & & & & \\
mining & $3.291^{* *}$ & 0.045 & & $1.027^{* *}$ & 0.021 \\
invest & $-0.344^{*}$ & 0.087 & & $-0.140^{* *}$ & 0.040 \\
gexpend & -0.450 & 0.145 & & -0.107 & 0.132 \\
topen & 0.304 & 0.296 & & 0.095 & 0.311 \\
error correction term & - & - & & $-0.312^{* * *}$ & 0.000 \\
Social sustainability & & & & \\
mining & $1.364^{*}$ & 0.063 & & $0.755^{*}$ & 0.083 \\
GDP & -0.100 & 0.183 & & $0.371^{* * *}$ & 0.000 \\
kstock & $0.478^{* * *}$ & 0.000 & & $0.264^{* * *}$ & 0.000 \\
hcapital & 0.649 & 0.112 & & $-8.933^{* * *}$ & 0.005 \\
error correction term & - & - & & $-0.553^{* * *}$ & 0.000 \\
Environmental sustainability & & & & \\
mining & 0.710 & 0.662 & & 0.417 & 0.675 \\
energy & $0.497^{*}$ & 0.086 & & $0.292^{*}$ & 0.056 \\
GDPC & 0.289 & 0.267 & & 0.170 & 0.283 \\
topen & 0.216 & 0.378 & & 0.127 & 0.403 \\
error correction term & - & - & & $-0.588^{* * *}$ & 0.001 \\
\hline
\end{tabular}

Note: $* * *, * *$ and $*$ represent the statistical significance at $1 \%, 5 \%$ and $10 \%$, respectively. revenues of mineral resources represent an important source for feeding the state budget, which may boost economic activity. It is also shown that the mining sector development also exerts positive and significant economic effects in the short-run. It is worth noting that the long-run effects of mining are higher than those of the short-run. Regarding the impact of mining on social sustainability, our results support a positive and significant long-run coefficient. Such results confirm the important role of the mining sector in boosting employment in the longrun. The mining sector also boosts employment in the short-run as the associated coefficient is statistically significant. Similar to economic sustainability, the table suggests that the impact of mineral resource rents is increasing over time. When estimating the impact of mineral resource rents on environmental sustainability, our results reveal the absence of any significant short- and long-run effects. It is important to mention that the negative and statistically significant error correction terms confirm that short-run disequilibrium is corrected and that the system will converge towards equilibrium in the long-run. To summarize, the previous analysis reveals that the mining sector development has been crucial for boosting economic activity and job creation in the short- and long-run. However, the adverse effects of mining on the environment are not confirmed.

\section{Are the long-run effects of mining on sustainable development robust?}

The current section aims to check the robustness of the long-run effects of mining on economic, social, and environmental sustainability. To this end, three robustness and sensitivity checks are conducted. We begin by implementing other cointegration tests. Then, we re-estimate the long-run effects using alternative estimators. Finally, we present results of the cumulative sum of squares of recursive residuals (CUSUM of squares) developed by Brown [74].

\subsection{Alternative cointegration tests}

To check the robustness of the ARDL findings regarding long-run relationships between mining and sustainable development, we employ the Gregory-Hansen cointegration test with an unknown structural break. Results associated with the three sustainable development dimensions using the four models are reported in Table 4.

Regarding economic sustainability, the first and second models reveal that the null hypothesis of no 
Table 4. Results of Gregory-Hansen cointegration test with an unknown structural break.

\begin{tabular}{|c|c|c|c|c|}
\hline \multirow[t]{2}{*}{ Dimension } & \multicolumn{2}{|l|}{$A D F_{t}^{*}$} & \multicolumn{2}{|c|}{ Decision } \\
\hline & t-statistic & $\mathrm{T}_{\mathrm{B}}$ & & \\
\hline \multicolumn{5}{|c|}{ Economic sustainability } \\
\hline Model 1 $(C)$ & -5.28 & 2004 & \\
\hline Model $2(C / T)$ & -5.04 & 2004 & \multicolumn{2}{|c|}{ cointegration } \\
\hline Model $3(C / S)$ & $-6.80^{* *}$ & 1990 & & \\
\hline Model $4(C / S / T)$ & $-8.59^{* * *}$ & 1990 & \\
\hline \multicolumn{3}{|c|}{ Social sustainability } & & \\
\hline Model $1(C)$ & $-5.35^{*}$ & 1987 & & \\
\hline Model $2(C / T)$ & $-5.65^{*}$ & 2006 & \multicolumn{2}{|c|}{ cointegration } \\
\hline Model 3 (C/S) & $-7.41^{* * *}$ & 1994 & & \\
\hline Model $4(C / S / T)$ & $-7.44^{* * *}$ & 1994 & & \\
\hline \multicolumn{3}{|c|}{ Environmental sustainability } & & \\
\hline Model 1 $(C)$ & -5.21 & 1995 & \multicolumn{2}{|c|}{ cointegration } \\
\hline Model $2(C / T)$ & $-6.08^{* *}$ & 1995 & & \\
\hline Model $3(C / S)$ & $-6.23^{*}$ & 1995 & & \\
\hline Model $4(C / S / T)$ & $-6.59^{*}$ & 1995 & & \\
\hline & & $1 \%$ & $5 \%$ & $10 \%$ \\
\hline Critical values & Model 1(C) & -6.05 & -5.56 & -5.31 \\
\hline & Model $2(C / T)$ & -6.36 & -5.83 & -5.59 \\
\hline & Model $3(\mathrm{C} / \mathrm{S})$ & -6.92 & -6.41 & -6.17 \\
\hline & Model $4(C / S / T)$ & -7.31 & -6.84 & -6.58 \\
\hline
\end{tabular}

Note: ***,**, and * denote the rejection of the null hypothesis of no cointegration at the $1 \%, 5 \%$, and $10 \%$ levels, respectively.

cointegration cannot be rejected. However, when considering Model 3, which allows the simultaneous presence of a mean break and a slope break, and Model 4, which allows a trend shift and a regime shift, the table reveals that economic sustainability and mineral resource rents are cointegrated. The Gregory-Hansen test also strongly supports the existence of cointegration between social sustainability and mineral resource rents. Indeed, the null hypothesis of no cointegration is rejected based on the four models. The same conclusion is reached when focusing on the cointegration between mineral resource rents and environmental degradation, as Models 2, 3, and 4 confirm the presence of a significant long-run association between variables. To summarize, the Gregory-Hansen cointegration test with an unknown structural break confirms results of the ARDL bounds testing approach by supporting the existence of long-run relationships between mineral resources rents and the three
Table 6. Alternative estimates of long-run effects.

\begin{tabular}{llllll}
\hline \multirow{2}{*}{ Dimension } & \multicolumn{2}{l}{ Fully modified OLS } & & \multicolumn{2}{l}{ Dynamic OLS } \\
\cline { 2 - 3 } \cline { 5 - 6 } & Coef. & p-value & & Coef. & p-value \\
\cline { 1 - 2 } Economic & sustainability & & & \\
mining & $4.747^{* * *}$ & 0.000 & & $4.004^{* * *}$ & 0.000 \\
invest & 0.083 & 0.521 & & 0.239 & 0.325 \\
gexpend & $-0.655^{* * *}$ & 0.000 & & $-0.433^{* * *}$ & 0.008 \\
topen & -0.014 & 0.933 & & -0.285 & 0.115 \\
Social sustainability & & & & \\
mining & $1.439^{* *}$ & 0.020 & & $2.624^{* *}$ & 0.017 \\
GDP & 0.040 & 0.446 & & $-0.284^{* *}$ & 0.018 \\
kstock & $0.775^{* * *}$ & 0.000 & & $0.451^{* *}$ & 0.017 \\
hcapital & $6.244^{* * *}$ & 0.000 & & $2.216^{* *}$ & 0.035 \\
Environmental sustainability & & & & \\
mining & $2.165^{*}$ & 0.088 & & 0.145 & 0.961 \\
energy & 0.470 & 0.259 & & 0.029 & 0.975 \\
GDPC & 0.255 & 0.177 & & 0.113 & 0.840 \\
topen & $0.310^{*}$ & 0.096 & & $0.647^{*}$ & 0.085 \\
\hline
\end{tabular}

Note: $* * * * *$ and $*$ represent the statistical significance at $1 \%, 5 \%$ and $10 \%$, respectively.

sustainable development dimensions (economic, social, environmental).

This study also implements Bayer [15] combined cointegration test. Findings are reported in Table 5. As shown, there is strong evidence of long-run relationships when considering the economic and social dimensions of sustainable development. Indeed, the two versions of the Bayer [15] test show that cointegration is confirmed at the $1 \%$ level. Regarding environmental sustainability, the same table reveals little evidence of a long-run relationship between environmental sustainability and mineral resource rents.

Overall, the Gregory-Hansen and combined cointegration tests confirm the ARDL findings suggesting the presence of long-run relationships between mineral resource rents on the one hand and the three sustainable development dimensions, on the other hand.

\subsection{Alternative estimators of long-run effects}

The current subsection aims to assess long-run effects using the fully modified OLS and dynamic OLS. The advantage of the fully modified OLS is

Table 5. Results of Bayer-Hanck combined cointegration test.

\begin{tabular}{lllll}
\hline Dimension & Model & $E G-J O H$ & $E G-J O H-B O-B D M$ & Decision \\
\hline Economic & $E c S=f($ mining, invest, topen, gexpend $)$ & $19.893^{* * *}$ & $130.417^{* * *}$ & cointegration \\
Social & $S o S=f($ mining, GDP, kstock, hcapital $)$ & $19.057^{* * *}$ & $55.898^{* * *}$ & cointegration \\
Environmental & EnS $=f($ mining, energy, topen, GDPC $)$ & $12.620^{* *}$ & $15.950^{*}$ & cointegration \\
Critical values & $1 \%$ & 15.845 & 30.774 & 20.143 \\
& $5 \%$ & 10.576 & 15.938 & \\
& $10 \%$ & 8.301 & & \\
\hline
\end{tabular}

Note: $* * *, * *$ and $*$ denote the rejection of the null hypothesis of no cointegration at the $1 \%, 5 \%$, and $10 \%$ levels, respectively. 
that it eliminates the sample bias and corrects the potential endogeneity and serial correlation, while the dynamic OLS avoids small sample bias and simultaneity problems. Findings are presented in Table 6.

The fully modified OLS and dynamic OLS findings confirm the positive long-run effects of mining on economic and social sustainability. Indeed, the

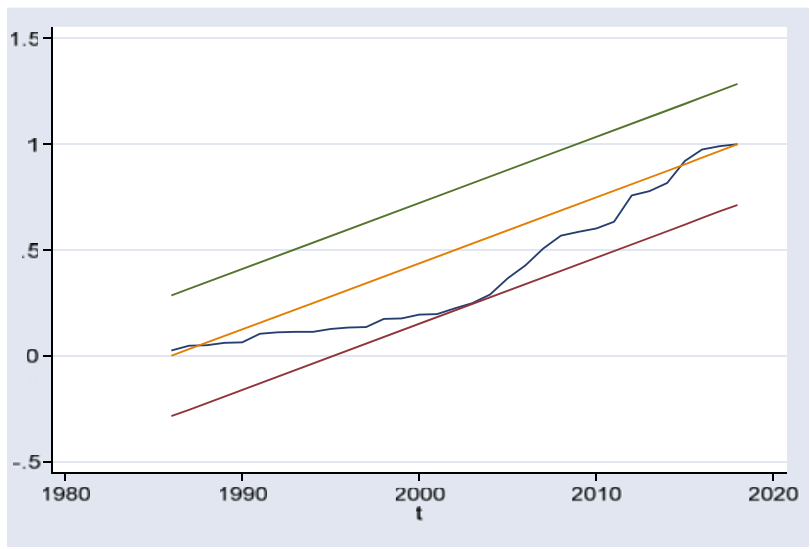

Economic sustainability

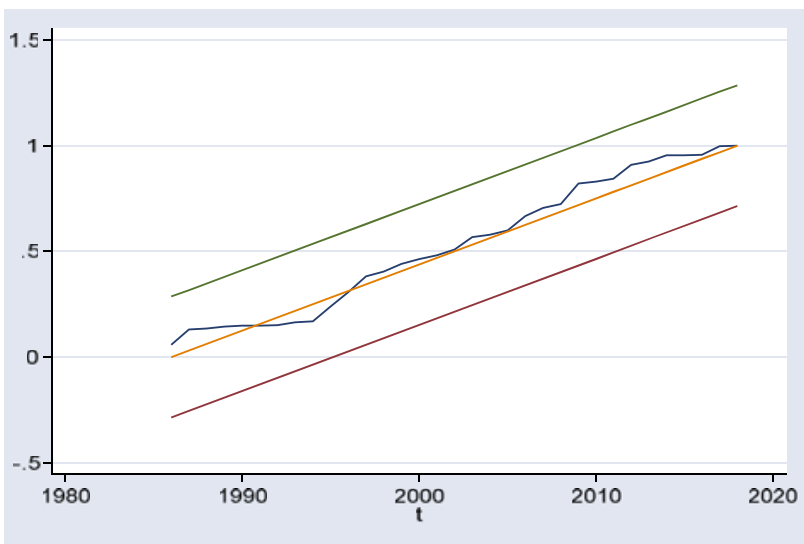

Social sustainability

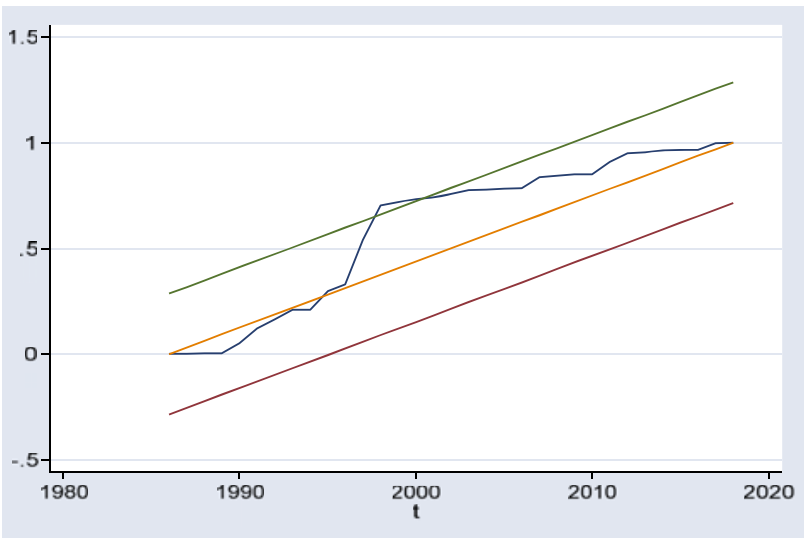

Environmental sustainability

Fig. 1. Plots of recursive CUSUM of squares test. estimated coefficients are positive and statistically significant. Therefore, one could conclude the robustness of the long-run economic and social effects of mining. However, when estimating the impact of mineral resource rents on environmental sustainability, the dynamic OLS results corroborate those of the ARDL, suggesting the absence of significant environmental impact. On the contrary, the fully modified OLS yields a positive but weakly significant coefficient (only at $10 \%$ ). There is, therefore, little evidence on the presence of significant adverse long-run effects of mining on environmental degradation.

\subsection{Stability of long-run effects}

The stability of ARDL long-run parameters is checked using the cumulative sum of squares of recursive residuals (CUSUM of squares) developed by Brown [74]. Figure 1 plots the output of the CUSUM of squares test and the associated 95\% confidence bands.

It can be observed that plots of the recursive CUSUM of squares processes do not generally cross the $95 \%$ confidence bands. Consequently, one may conclude the robustness of findings and the absence of instability. These findings provide an argument on the stability of the long-run effects of mining on the economic, social, and environmental pillars of sustainability in Saudi Arabia.

\section{Conclusions and policy recommendations}

This study examines the effects of mining sector development on the three pillars of sustainable development in Saudi Arabia between 1980 and 2018. The empirical investigation aims to estimate the short- and long-run effects of mining on economic, social, and environmental sustainability. To examine the presence of long-run relationships, we use the ARDL modelling, the Gregory-Hansen cointegration test with an unknown structural break, and the combined cointegration test. The three different cointegration tests confirm the existence of long-run relationships between mining on the one hand and economic, social, and environmental sustainability on the other hand. When estimating the long-run effects of mining, the three used estimators, namely the ARDL, fully modified OLS, and Dynamic OLS, suggest the existence of positive long-run effects on attaining the economic and social sustainability objectives. However, the findings do not support the presence of long-run adverse effects of mining on the environment. The same results are found when conducting the short- 
run analysis, as the mining sector development boosts the economic and social sustainability without harming the environment. An important issue that may arise is that the magnitude of mining's effects on the economy and society is higher in the long-run than in the short-run.

Based on the findings of this research, a set of policy recommendations may be drawn. First, the business environment related to the mining sector should be improved. For example, more participation of domestic and foreign investors in the exploration and exploitation activities should be encouraged. Second, policymakers are invited not only to encourage mining exploration and extraction activities, but also mining-related industries, such as office supplies, spare parts, machinery, and maintenance services. The development of these activities could enhance economic activity and job creation. Moreover, although our results suggest the absence of significant adverse environmental effects of mining, it is preferred to manage the presence of potential effects of mining exploitation after the mine closes in the very long-run. To this end, policymakers may implement various policies, such as the creation of a clear and efficient waste management plan for new mining projects and the use of new production technologies using fewer chemical products and explosives.

Although the current research provides some interesting findings regarding the impact of the mining sector on sustainable development in Saudi Arabia, some perspectives for future studies may be presented. First, one could examine the effects of mining on sustainable development at the regional level. Regarding this issue, it is of interest to assess the role played by the mining sector in miningabundant regions in Saudi Arabia, such as the Northern Border region. This analysis may be carried out using survey-based datasets collected from local communities in mining-abundant regions. Second, future studies may employ alternative sustainable development indicators, such as life expectancy, per capita consumption, access to education, deforestation, land-use transformation, and soil degradation. Finally, the current research may be extended by investigating the effects of various natural resources, such as oil, natural gas, and mining, on sustainable development. Such an analysis allows comparing the reaction of the various sustainable development dimensions to natural resources.

\section{Ethical statement}

The authors state that the research was conducted according to ethical standards.

\section{Funding body}

The authors extend their appreciation to the Deputyship for Research \& Innovation, Ministry of Education in Saudi Arabia for funding this research work through the project number "IF_2020_2203".

\section{Conflicts of interest}

None declared.

\section{Appendix.}

Table A1. Definitions and sources of data.

\begin{tabular}{|c|c|c|}
\hline Variable & Definition & Source \\
\hline$E c S$ & $\begin{array}{l}\text { Economic } \\
\text { sustainability as } \\
\text { measured by GDP per } \\
\text { capita. }\end{array}$ & $\begin{array}{l}\text { World Development } \\
\text { Indicators, World Bank }\end{array}$ \\
\hline SoS & $\begin{array}{l}\text { Social sustainability as } \\
\text { measured by total } \\
\text { employment }\end{array}$ & $\begin{array}{l}\text { Penn World Table, } \\
\text { version } 9.1\end{array}$ \\
\hline EnS & $\begin{array}{l}\text { Environmental } \\
\text { sustainability as } \\
\text { measured by } \mathrm{CO} 2 \\
\text { emissions per capita }\end{array}$ & $\begin{array}{l}\text { Energy Information } \\
\text { Administration }\end{array}$ \\
\hline mining & $\begin{array}{l}\text { Mineral rents }(\% \text { of } \\
\text { GDP) }\end{array}$ & $\begin{array}{l}\text { World Development } \\
\text { Indicators, World Bank }\end{array}$ \\
\hline topen & $\begin{array}{l}\text { Trade openness as } \\
\text { measured by the sum } \\
\text { of exports and imports } \\
(\% \text { of GDP) }\end{array}$ & $\begin{array}{l}\text { World Development } \\
\text { Indicators, World Bank }\end{array}$ \\
\hline energy & $\begin{array}{l}\text { Total energy } \\
\text { consumption per } \\
\text { capita }\end{array}$ & $\begin{array}{l}\text { Energy Information } \\
\text { Administration }\end{array}$ \\
\hline invest & $\begin{array}{l}\text { Gross fixed capital } \\
\text { formation ( } \% \text { of GDP) }\end{array}$ & $\begin{array}{l}\text { World Development } \\
\text { Indicators, World Bank }\end{array}$ \\
\hline gexpend & $\begin{array}{l}\text { General government } \\
\text { final consumption } \\
\text { expenditure }(\% \text { of } \\
\text { GDP) }\end{array}$ & $\begin{array}{l}\text { World Development } \\
\text { Indicators, World Bank }\end{array}$ \\
\hline GDP & $\begin{array}{l}\text { Real gross domestic } \\
\text { product }\end{array}$ & $\begin{array}{l}\text { World Development } \\
\text { Indicators, World Bank }\end{array}$ \\
\hline hcaptial & Human capital index & $\begin{array}{l}\text { Penn World Table, } \\
\text { version } 9.1\end{array}$ \\
\hline kstock & Real capital stock & $\begin{array}{l}\text { Penn World Table, } \\
\text { version } 9.1\end{array}$ \\
\hline
\end{tabular}

\section{References}

[1] Turan T, Yanıkkaya H. Natural resource rents and capital accumulation nexus: do resource rents raise public human and physical capital expenditures? Environ Econ Pol Stud 2020;22:449-66. https://doi.org/10.1007/s10018-020-00264-9.

[2] Kitula AGN. The environmental and socioeconomic impacts of mining on local livelihoods in Tanzania: a case study of Geita District. J Clean Prod 2006;14:405-14. https://doi.org/ 10.1016/j.jclepro.2004.01.012.

[3] Syahrir R, Wall F, Diallo P. Socioeconomic impacts and sustainability of mining, a case study of the historical tin 
mining in Singkep Island-Indonesia. Extr. Ind. Soc. 2020;7: 1525-33. https://doi.org/10.1016/j.exis.2020.07.023.

[4] Ticci E. Escobal J. Extractive industries and local development in the Peruvian Highlands. Environ Dev Econ 2015;20: 101-26. https://doi.org/10.1017/S1355770X13000685.

[5] Loayza N, Rigolini J. The local impact of mining on poverty and inequality: evidence from the commodity boom in Peru. World Dev 2016;84:219-34. https://doi.org/10.1016/ j.worlddev.2016.03.005.

[6] Davis GA, Tilton JE. Should developing countries renounce mining? A perspective on the debate. Report prepared for the International Council on Mining and Metals. London: ICMM; 2002.

[7] Labonne B. Commentary: harnessing mining for poverty reduction, especially in Africa. Nat Resour Forum 2002;26: 69-73. https://doi.org/10.1111/1477-8947.00007.

[8] Mbilima F. Extractive industries and local sustainable development in Zambia: the case of corporate social responsibility of selected metal mines. Resour Pol 2019:101441. https://doi.org/10.1016/j.resourpol.2019.101441.

[9] The Extractive Industries Transparency Initiative. Rapport contextuel ITIE-RDC 2017-2018. 2019.

[10] Sahsah M. Naissance et développement d'une ville minière marocaine: khouribga. Doctoral dissertation, Université Jean-Monnet-Saint-Étienne. 1996.

[11] Brahmi M, Zouari S, Rossi ML, industrie minière et ses effets écologiques. État socio-économique et environnemental dans le bassin minier tunisien. Collection EDYTEM. Cahiers de géographie 2014;17:109-20. https://doi.org/10.3406/ edyte.2014.1279.

[12] Mabey PT, Li W, Sundufu AJ, Lashari AH. Environmental impacts: local perspectives of selected mining edge communities in Sierra Leone. Sustainability-Basel 2020;12:5525. https://doi.org/10.3390/su12145525.

[13] The Saudi General Investment Authority. Mining \& metals. 2020. Available at: https://investsaudi.sa/media/2101/ mining-and-metal.pdf. [Accessed 25 January 2021].

[14] Pesaran MH, Shin Y, Smith RJ. Bounds testing approaches to the analysis of level relationships. J Appl Econ 2001;16: 289-326. https://doi.org/10.1002/jae.616.

[15] Bayer C, Hanck C. Combining non-cointegration tests. J. Time Ser. Anal. 2013;34:83-95. https://doi.org/10.1111/ j.1467-9892.2012.00814.x.

[16] El Hachimi ML, El Hanbali M, Fekhaoui M, Bouabdli A, EL Founti L, Saïdi N. Impact d'un site minier abandonné sur l'environnement: cas de la mine de Zeïda (Haute Moulouya, Maroc). Bulletin de l'Institut Scientifique, Rabat, section Sciences de la Terre 2005;27:93-100.

[17] Sala-i-Martin X, Doppelhofer G, Miller RI. Determinants of long-term growth: a Bayesian averaging of classical estimates (BACE) approach. Am Econ Rev 2004;94:813-35.

[18] Sangare S, Maisonnave H. Mining and petroleum boom and public spending policies in Niger: a dynamic computable general equilibrium analysis. Environ Dev Econ 2018;23: 580-90. https://doi.org/10.1017/S1355770X18000104.

[19] Gueye EHM, Badri A, Boudreau-Trudel B. Sustainable development in the mining industry: towards the development of tools for evaluating socioeconomic impact in the Canadian context. Environ Dev Sustain 2020:1-27. https:// doi.org/10.1007/s10668-020-00948-y.

[20] Huang X, Faysse N, Ren X. A multi-stakeholder platform involving a mining company and neighbouring villages in China: back to development issues. Resour Pol 2017;51: 243-50. https://doi.org/10.1016/j.resourpol.2017.01.005.

[21] Prebisch R. The economic development of Latin America and its principal problems. New York: United Nations; 1950.

[22] Singer $\mathrm{H}$. The distribution of gains between investing and borrowing countries. Am Econ Rev 1950;40:473-85.

[23] Davis GA, Tilton JE. Why the resource curse is a concern. Min. Eng-Littleton 2008;60:29-32.

[24] Cowell SJ, Wehrmeyer W, Argust PW, Robertson JGS. Sustainability and the primary extraction industries: theories and practice. Resour Pol 1999;25:277-86. https://doi.org/ 10.1016/S0301-4207(00)00003-9.

[25] Stern DI. The contribution of the mining sector to sustainability in developing countries. EcolEcon 1995;13:53-63. https://doi.org/10.1016/0921-8009(94)00057-3.

[26] Douglas S, Walker A. Coal mining and the resource curse in the eastern United States. J. Regional Sci. 2017;57:568-90. https://doi.org/10.1111/jors.12310.

[27] Kotsadam A, Tolonen A. African mining, gender, and local employment. World Dev. 83, 325-339. https://doi.org/10. 1016/j.worlddev.2016.01.007.

[28] Monteiro NBR, da Silva EA, Neto JMM. Sustainable development goals in mining. J Clean Prod 2019;228:509-20.

[29] Dubiński J. Sustainable development of mining mineral resources. J. Sustain. Min. 2013;12:1-6. https://doi.org/10.7424/ jsm130102.

[30] Popović V, Jž Miljković, Subić J, Jean-Vasile A, Adrian N, Nicolăescu E. Sustainable land management in mining areas in Serbia and Romania. Sustainability-Basel 2015;7:11857-77. https://doi.org/10.3390/su70911857.

[31] Dudka S, Adriano DC. Environmental impacts of metal ore mining and processing: a review. J Environ Qual 1997;26:590-602. $00472425002600030003 x$

[32] Sha-Sha FU, Pei-Jun LI, Qian FENG, Xiao-Jun LI, Peng LI, Yue-Bing SUN, et al. Soil quality degradation in a magnesite mining area. Pedosphere 2011;21:98-106. https://doi.org/ 10.1016/S1002-0160(10)60084-7.

[33] Wright IA, Paciuszkiewicz K, Belmer N. Increased water pollution after closure of Australia's longest operating underground coal mine: a 13-month study of mine drainage, water chemistry and river ecology. Water Air Soil Pollut 2018;229:1-20. https://doi.org/10.1007/s11270-018-3718-0.

[34] Mhlongo S, Mativenga PT, Marnewick A. Water quality in a mining and water-stressed region. J Clean Prod 2018;171: 446-56. https://doi.org/10.1016/j.jclepro.2017.10.030.

[35] Price P, Wright IA. Water quality impact from the discharge of coal mine wastes to receiving streams: comparison of impacts from an active mine with a closed mine. Water Air Soil Pollut 2016;227:155. https://doi.org/10.1007/s11270-016-2854-7.

[36] Sairinen R, Tiainen $H$, Mononen T. Talvivaara mine and water pollution: an analysis of mining conflict in Finland. Extr. Ind. Soc. 2017;4:640-51. https://doi.org/10.1016/ j.exis.2017.05.001.

[37] Li F, Li X, Hou L, Shao A. Impact of the coal mining on the spatial distribution of potentially toxic metals in farmland tillage soil. Sci. Rep.-UK 2018;8:1-10. https://doi.org/10.1038/ s41598-018-33132-4.

[38] S\&P Global Market Intelligence. Top 25 mining companies by market capitalization. 2018. Available at: https://www. spglobal.com/marketintelligence/en/news-insights/ research/18-top-25-mining-companies-by-market-cap (accessed on February 05, 2021).

[39] Taib M. The mineral industry of Saudi Arabia, 2015 minerals yearbook. U.S. Geological Survey 2019:60.1-60.10.

[40] Anderson D. Investment and economic growth. World Dev 1990;18:1057-79. https://doi.org/10.1016/0305-750X(90)90088-F.

[41] Khan MS, Reinhart CM. Private investment and economic growth in developing countries. World Dev 1990;18:19-27. https://doi.org/10.1016/0305-750X(90)90100-C.

[42] Ben-Salha O, Zmami M. The impact of private capital flows on economic growth in the MENA region. Econ Bus Rev 2020;6:45-67. https://doi.org/10.18559/ebr.2020.3.3.

[43] Grossman GM, Helpman E. Innovation and growth in the global economy. Cambridge, MA: MIT Press; 1991.

[44] Edwards S. Openness, trade liberalization, and growth in developing countries. J Econ Lit 1993;31:1358-93.

[45] Goaied M, Sassi S. Trade liberalisation and employment intensity of sectoral output growth: lessons from Tunisia. Econ Lab Relat Rev 2015;26:261-75. https://doi.org/10.1177/ 1035304615579833.

[46] Ghazali M, Mouelhi R. The employment intensity of growth: evidence from Tunisia. J Econ Dev 2018;43:85-117. 
[47] Ben-Salha O, Zmami M. The effect of economic growth on employment in GCC countries. Sci. Ann. Econ. Bus. 2021;68: 25-41. https://doi.org/10.47743/saeb-2021-0004.

[48] Boltho A, Glyn A. Can macroeconomic policies raise employment? Int Lab Rev 1995;134:452-70.

[49] Ben-Salha O. Does economic globalization affect the level and volatility of labor demand by skill? New insights from the Tunisian manufacturing industries. Econ Syst 2013;37: 572-97. https://doi.org/10.1016/j.ecosys.2013.07.006.

[50] Zmami $M$, Ben-Salha O. Exchange rate movements and manufacturing employment in Tunisia: do different categories of firms react similarly? Econ Change Restruct 2015;48: 137-67. https://doi.org/10.1007/s10644-015-9158-6.

[51] Pattanaik F, Nayak NC. Macroeconomic determinants of employment intensity of growth in India. Margin. J. Appl. Econ. Res. 2014;8:137-54. https://doi.org/10.1177/ 0973801013519997.

[52] Khoshnevis Yazdi S, Shakouri B. The renewable energy, $\mathrm{CO} 2$ emissions, and economic growth: VAR model. Energ. Source. Part. B. 2018;13:53-9. https://doi.org/10.1080/ 15567249.2017.1403499.

[53] Ben Jebli M, Farhani S, Guesmi K. Renewable energy, CO2 emissions and value added: empirical evidence from countries with different income levels. Struct Change Econ Dynam 2020;53:402-10. https://doi.org/10.1016/ j.strueco.2019.12.009.

[54] Omri A, Belaiid F. Does renewable energy modulate the negative effect of environmental issues on the socio-economic welfare? J Environ Manag 2021;278:111483. https:// doi.org/10.1016/j.jenvman.2020.111483.

[55] Grossman GM, Krueger AB. Economic growth and the environment. Q J Econ 1995;110:353-77. https://doi.org/ $10.2307 / 2118443$.

[56] Jayanthakumaran K, Verma R, Liu Y. CO2 emissions, energy consumption, trade and income: a comparative analysis of China and India. Energy Pol 2012;42:450-60. https://doi.org/ 10.1016/j.enpol.2011.12.010.

[57] Zmami M, Ben-Salha O. An empirical analysis of the determinants of $\mathrm{CO} 2$ emissions in GCC countries. Int. J. Sust. Dev. World. 2020;27:469-80. https://doi.org/10.1080/ 13504509.2020.1715508.

[58] Bilan Y, Streimikiene D, Vasylieva T, Lyulyov O, Pimonenko T, Pavlyk A. Linking between renewable energy, $\mathrm{CO} 2$ emissions, and economic growth: challenges for candidates and potential candidates for the EU membership. Sustainability-Basel 2019;11:1528. https://doi.org/10.3390/ su11061528.

[59] Das M, Das SK. Distribution neutral abatement policy in a model of trade and environment. Environ Dev Econ 2009;14: 457-72. https://doi.org/10.1017/S1355770X09005191.
[60] Copeland BR, Taylor MS. International trade and the environment: a framework for analysis. In: NBER working paper No. 8540; 2001.

[61] Ben Jebli M, Youssef SB. Timing of adoption of clean technologies, transboundary pollution and international trade. Economics-Kiel. 2014;8:1-31. https://doi.org/10.5018/economics-ejournal.ja.2014-19.

[62] Elliott G, Rothenberg TJ, Stock JH. Efficient tests for an autoregressive unit root. Econometrica 1996;64:813-36. https://doi.org/10.2307/2171846.

[63] Saikkonen P, Lütkepohl H. Testing for a unit root in a time series with a level shift at unknown time. Econ Theor 2002; 18(2):313-48. https://doi.org/10.1017/S0266466602182053.

[64] Lanne M, Lütkepohl H, Saikkonen P. Comparison of unit root tests for time series with level shifts. J. Time Ser. Anal. 2002;23: 667-85. https://doi.org/10.1016/S0165-1765(01)00593-6.

[65] Kripfganz S, Schneider DC. Response surface regressions for critical value bounds and approximate $p$-values in equilibrium correction models. Oxf Bull Econ Stat 2020;82:1456-81. https://doi.org/10.1111/obes.12377.

[66] Gregory AW, Hansen BE. Residual-based tests for cointegration in models with regime shifts. J Econom 1996a;70: 99-126. https://doi.org/10.1016/0304-4076(69)41685-7.

[67] Gregory AW, Hansen BE. Practitioners corner: tests for cointegration in models with regime and trend shifts. Oxf Bull Econ Stat 1996b;58:555-60. https://doi.org/10.1111/ j.1468-0084.1996.mp58003008.x.

[68] Engle RF, Granger CW. Co-integration and error correction: representation, estimation, and testing. Econometrica 1987; 55:251-76. https://doi.org/10.2307/1913236.

[69] Johansen S. Statistical analysis of cointegration vectors. J Econ Dynam Contr 1998;12:231-54. https://doi.org/10.1016/ 0165-1889(88)90041-3.

[70] Boswijk HP. Testing for an unstable root in conditional and structural error correction models. J Econom 1994;63:37-60. https://doi.org/10.1016/0304-4076(93)01560-9.

[71] Banerjee A, Dolado J, Mestre R. Error-correction mechanism tests for cointegration in a single-equation framework. J. Time Ser. Anal. 1998;19:267-83. https://doi.org/10.1111/ 1467-9892.00091.

[72] Phillips PC, Hansen BE. Statistical inference in instrumental variables regression with I (1) processes. Rev Econ Stud 1990; 57:99-125. https://doi.org/10.2307/2297545.

[73] Stock JH, Watson MW. A simple estimator of cointegrating vectors in higher order integrated systems. Econometrica 1993;61:783-820. https://doi.org/10.2307/2951763.

[74] Brown RL, Durbin J, Evans JM. Techniques for testing the constancy of regression relationships over time. J. Roy. Stat. Soc. B. Met. 1975;37(2):149-63. https://doi.org/10.1111/j.25176161.1975.tb01532.x. 